\title{
Making Sense of Competitive Authoritarianism: Lessons from the Andes
}

Maxwell A. Cameron

\begin{abstract}
Scholarly attention has increasingly shifted from diminished subtypes of democracy to hybrid regimes, particularly competitive authoritarianism. Such regimes retain democracy's formal features while failing to meet its minimum standards. When properties of distinct concepts like democracy and authoritarianism are combined, however, confusion, inaccuracy, and mischaracterization of cases may occur. By disaggregating political systems into electoral institutions, surrounding rights and freedoms, constitutionalism, and the rule of law, this article complicates the binary distinction between a midrange definition of democracy and competitive authoritarianism. A number of Andean cases are found to fall on the spectrum of defective democracies between these categories. Defective democracies break down when rulers violate the conditions necessary for institutionalized alternation in power by means of public participation and loyal opposition in an electoral regime. Given leaders' reliance on electoral legitimacy, however, even defective democracies may prove surprisingly resilient.
\end{abstract}

Keywords: defective democracy, competitive authoritarianism, hybrid regimes, rule of law, constitutionalism, Andean countries

Tn their landmark work Transitions from Authoritarian Rule: Tentative Conclusions About Uncertain Democracies (1986), Guillermo O’Donnell and Philippe C. Schmitter largely bracketed the definition of democracy, for reasons that made sense at that historical juncture. They rightly assumed most contemporary actors would agree that democracy entailed, at a minimum, universal suffrage, the secret ballot, regular elections, party competition, and freedom of association (1986, 8). They also anticipated the subsequent discussion of hybrid regimes by distinguishing between liberalization and democratization, the juxtaposition of which generated such categories as limited political democracy (democradura) and liberalized autocracy (dictablanda).

A subsequent shift in the focus of research from transitions to the consolidation of democracy was fraught with greater definitional controversy, however, as theories based on European and North American experience proved ill-suited to the political context of Latin America. Ten years after the publication of Transitions, O'Donnell

Maxwell A. Cameron is a professor of political science at the University of British Columbia. Max.Cameron@ubc.ca 
(1996) delivered a devastating broadside to the idea of democratic consolidation, which he suggested was Eurocentric and teleological. He identified a "new monster," delegative democracy, in which presidents were elected freely and fairly but governed undemocratically; that is, without checks and balances or "horizontal accountability" (O’Donnell 1998). Other scholars coined similar terms, like "illiberal" (Zakaria 1997) or "defective" democracies (Merkel 2004; Bogaards 2009). The proliferation of democracies "with adjectives," or "diminished subtypes" of democracy, was noted in an influential article by David Collier and Steven Levitsky (1997). ${ }^{1}$

Challenges to democracy continued to mount in the decades following O'Donnell's critique. Although military coups and systematic electoral fraud remained rare, subtler threats to democracy emerged: pacts negotiated during transitions broke down, sometimes with destabilizing effects; populism and plebiscitary rule flourished; party systems collapsed, giving rise to crises of representation; democratic mandates were interrupted; and in extreme cases, democratic institutions were shuttered, fundamental rights and freedoms were violated, spaces for opposition were restricted, and possibilities for democratic alternation in power were imperiled (Slater 2013; Pérez-Liñán 2007; Roberts 2007; Weyland 2013; Valenzuela 2004; Mainwaring et al. 2006; Cameron and Luna 2010). Despite widespread recognition of the parlous state of democracy, sharp differences of interpretation emerged. For some, the early decades of the twenty-first century heralded the "end of the transitions era" and the beginning of a period of "democratic recession" (Diamond 2015; Plattner 2014; also Carothers 2002).

In this pessimistic milieu, scholars shifted their attention from diminished subtypes of democracy to hybrid regimes. In hybrid regimes, rulers not only exceeded the constitutional limits of their powers but also violated the conditions necessary for the construction of democratic mandates. In pathbreaking contributions, Steven Levitsky and Lucan Way (2002, 2010a) proposed the concept of competitive authoritarianism. ${ }^{2}$ The concept, and cognates like electoral authoritarianism and protected democracy, captured an important insight: elections are not only insufficient to designate a regime as a democracy, they have often played an important role in authoritarian systems. Such regimes may retain democracy's formal features while, in practice, failing to meet its minimum standards.

Although the discussion of hybrid regimes is welcome, scholarship that mixes features of different regime types may generate conceptual confusion unless accompanied by criteria for determining when regimes fall short of democratic standards. ${ }^{3}$ This article focuses on ambiguities arising from the concept of competitive authoritarianism, and it cautions against treating too many regimes as subtypes of authoritarianism when they may simply be low-quality democracies in which governments are operating under severe stresses, or even breaking down, without necessarily transitioning to a new type of regime. In the face of these ambiguities, an appropriate strategy may be to disaggregate political systems into components.

The article begins by noting three conceptual challenges competitive authoritarianism creates for scholarship: the definition of an uneven playing field, the use of a midrange definitional bar for democracy, and the identification of features of 
authoritarianism. It draws on O'Donnell 2010 to distinguish the electoral components of a democratic regime, surrounding rights and freedoms, constitutionalism, and the rule of law. ${ }^{4}$ This framework is used to suggest solutions to the "cat-dog problem" presented by competitive authoritarianism: how to theorize hybrids while upholding the conceptual boundaries between root concepts. Armed with these tools, the article reviews the cases of competitive authoritarianism identified by Levitsky and Loxton (2013).

In two regimes-Peru after Fujimori's autogolpe (1992-2000) and Venezuela since the election of Chávez (1998-present, especially after 2006) — that were found to meet the criteria of competitive authoritarianism, outsider politicians relied on de facto powers to perpetuate themselves in power. This was not the case, however, in two other regimes-Bolivia under Evo Morales (2006-present) and Ecuador since the election of Rafael Correa (2007-present) — which also met the criteria. ${ }^{5}$ The article concludes by considering the relevance of this analysis for policymakers.

The aim of this article is to set a research agenda by sharpening our understanding of certain theoretical concepts and relationships, rather than to provide a better specification of measures or indicators. Democracy cannot be defined in terms of a set of institutions until we specify what makes those institutions democratic. For that, we must examine how democracies work and determine the goals they may be expected to attain - that is, the intrinsic aims of the institutions themselves. As Giovanni Sartori put it, "what democracy is cannot be separated from what democracy should be" (1962, 4-5). Rather than help the perplexed observer to classify cases correctly, this article exposes a set of conceptual problems that must be addressed before we can make valid observations. To cite Sartori again: we "cannot measure before conceptualizing" (1970, 64).

\section{The Elements of Competitive Authoritarianism}

Levitsky and Way define competitive authoritarian systems as

civilian regimes in which formal democratic institutions exist and are widely viewed as the primary means of gaining power, but in which incumbents' abuse of the state places them at a significant advantage vis-à-vis their opponents. Such regimes are competitive in that opposition parties use democratic institutions to contest seriously for power, but they are not democratic because the playing field is heavily skewed in favor of incumbents. Competition is thus real but unfair. (Levitsky and Way 2010a, 5).

This definition - the point of departure for one of the most influential books on political regimes in recent years - poses at least three theoretical problems for the analyst. First is the ambiguity about the meaning of a "reasonably level playing field" (Levitsky and Way 2010a, 7). This is a crucial refinement of democratic theory, but it creates a conceptual challenge: at what point does an unlevel playing field for the opposition make an otherwise democratic regime authoritarian? This is a problem 
of theory rather than measurement. Levitsky and Way define the unevenness of the playing field in terms of access to state resources, public media, and justice. Explicit criteria are needed to assess whether the advantages conferred on incumbents, and handicaps for the opposition, are so great as to make the system undemocratic (2010a, 10). ${ }^{6}$

Likewise, such criteria are necessary for the assertion that competition is too "unfair" for a regime to be democratic or that the playing field is so uneven that opposition activity is "seriously impaired" (Levitsky and Way 2010b, 57). ${ }^{7}$ The task is complicated, however, by Levitsky and Way's insistence that opposition groups in competitive authoritarian regimes "contest seriously for power" (2010a, 5). In other words, the lack of a reasonably level playing field notwithstanding, elections are still competitive-albeit unfair. There are still "meaningful democratic institutions" (Levitsky and Way 2010a, 20) within these erstwhile authoritarian regimes. ${ }^{8}$ What does it mean to say that there are meaningful elections in which opponents compete seriously for power but competition is so stacked against the opposition as to make the regime nondemocratic? The answer to this puzzle lies in Levitsky and Way's definition of democracy.

The second problem is that Levitsky and Way (2010a, 5-6) set a midrange definitional bar. Instead of starting with a minimalist, procedural definition of democracy, they adopt a "procedural but demanding" definition that includes all the "Schumpeterian" features of democracy necessary for competitive elections plus "the existence of a reasonably level playing field between incumbents and opposition." Thus, a regime is categorized as competitive authoritarian if there is evidence of any one of a range of violations of civil liberties—including attacks on or harassment of the media, restrictions on freedom of association and speech, attacks on opposition figures - or if the playing field is uneven in any of the respects mentioned above (Levitsky and Way 2010a, 366-68).

Although this is a valid strategy, it is potentially problematic in a region in which political regimes are often more democratic but less liberal than in established representative democracies (O'Donnell 1994, 60). If the definitional bar is set at midrange, diminished subtypes of democracy may fail to meet Levitsky and Way's higher - implicitly liberal—standard and thus be misclassified as authoritarian. As we shall see, this "conceptual stretching" (Collier and Levitsky 1997) is precisely what occurs when Levitsky and Way's framework is applied in the Andean region (Levitsky and Loxton 2013).

Third, although competitive authoritarianism is a subtype of authoritarianism, it is defined primarily in terms of the attributes of democracy it lacks, such as multiparty elections or freedom for opposition groups to operate in the public sphere (Bogaards 2009, 401). A key feature of authoritarianism, "unelected tutelary powers," is explicitly excluded from the definition of competitive authoritarianism (Levitsky and Way 2010a, 365). To make the case that a regime has degenerated past the point of being democratic, it would be helpful to specify more fully and to justify in theoretical terms the features or conditions that make a regime one type or another (Bogaards 2009, 410-15; Morse 2012). It may be valid, for certain pur- 
poses, to draw a conceptual boundary between regime types without fully specifying features on both sides of the conceptual coin; nevertheless, doing so can result in a loss of clarity and focus. For example, one essential function or aim of democracy is the opportunity to remove incumbents at election time. Authoritarianism is the mirror-opposite: rulers depend on coercion rather than electoral legitimacy.

Keeping both these ideas in mind helps us to grasp the difference between the two regimes. Put differently, the existence of unelected de facto powers is a key attribute of authoritarianism, just as its absence is a useful refinement of the concept of democracy (Levitksy and Way 2010a, 368, 6). To pursue these ideas further, the next section disaggregates democratic political systems into their components.

\section{DisAggregating DEMOCRACY}

A distinctive feature of qualitative research is a strong focus on concepts- the building blocks of theory (Goertz 2006; Sartori 1970, 1991; Collier and Levitsky 1997, 2009). Case-oriented comparative research requires the accurate constitution of cases (Ragin 1997). The approach to concepts exemplified in this article is realistic, problem-based, and causal. It is realistic because the concept of democracy adopted usefully captures real-world cases and enables their empirical assessment ( $\mathrm{O}^{\prime}$ Donnell 2001, 11-12). It is problem-based because democracy is defined not in terms of arbitrary lists of attributes, whether drawn from existing cases or ideal types, but in terms of the conditions that enable it to operate democratically (Warren 2017). To determine whether a case is a democracy, we may ask, what problems must democracies solve in order to constitute cases of democracy? It is causal because it seeks to identify the operations that sustain even defective democracies and to determine how and why democracies break down when key components are missing.

For the purpose of analysis, this article stipulates that democracy is a system of institutionalized alternation in power by means of public participation and loyal opposition in an electoral system. If a regime attains these goals, it is a democracy. This is a realistic standard against which to assess the performance of concrete institutions. Democracies are regimes that contain both electoral components and the concomitant conditions necessary to make them arenas of meaningful alternation and contestation. Constitutionalism and the rule of law, although not part of the definition of democracy, help institutionalize democratic regimes and prevent their erosion.

\section{Electoral Components of the Democratic Regime}

At the core of any modern democratic system are its electoral components. The electoral regime contains institutional attributes based on Robert Dahl's concept of polyarchy that concern voting: officials acquire the right to hold public office by means of periodic elections; electoral processes are not fraudulent; all qualified citizens have the right to vote; and all citizens are eligible to run for office (Dahl 1989, 120, 1973; O'Donnell 2010, 17-18; see table 1). 
Table 1. Components of Democratic Systems

A. Electoral Components

1. Officials acquire the right to hold public office by means of periodic elections.

2. Electoral processes are not fraudulent.

3. All qualified citizens have the right to vote.

4. All eligible citizens can run for office.

B. Concomitant Conditions

5. All citizens enjoy freedom of expression.

6. All citizens enjoy freedom of association and assembly.

7. All citizens have access to alternative sources of information, and certain other rights and freedoms that cannot be stipulated a priori.

C. Constitutionalism and the Rule of Law

8. The state is organized to ensure horizontal accountability.

9. The state enforces the rule of law.

10. Civilians have supremacy over the armed forces, which are nondeliberative and obedient.

D. Refinements

11. Elected officials are not subject to control by nonelected officials, either through "authoritarian enclaves" in the state or overt military interference in civilian affairs.

12. Nonelected officials or pressure groups will not arbitrarily terminate the mandate of elected officials.

13. The opposition has an equitable playing field with respect to access to justice, the media, and state resources.

These attributes help political systems attain at least three goals. First, elections foster institutionalized agreement. ${ }^{9}$ The electoral regime ensures that alternation between government and opposition follows established rules. Elections result in winners and losers (Przeworski 1991), but the aim of electoral contestation is to ensure acceptance of the winner's authority to rule. For this agreement to be as universal as possible, all citizens must have the right to vote or run for office in free and fair elections, and whoever is elected must be able to hold public office.

Second, elections resolve conflict. Those who win elections are empowered to hold office and make binding decisions, provided they operate within the terms of their mandates (O'Donnell 2010, 18-19). Any indication of systematic fraud naturally undermines the decisiveness of elections, but the practice of denouncing fraud, regardless of evidence, may bespeak a precariously institutionalized opposition. The integrity and independence of electoral institutions is a vital guarantor that the voting results can be trusted.

Third, elections enable the exercise of citizenship rights. By voting, citizens, in principle, freely express their intentions. These are valid, however, only if expressed by agents who have "the title to be recognized, and legally backed, as the holder of rights" (O'Donnell 2010, 1). Moreover, each vote must be weighted equally and counted honestly. Any misrepresentation of the vote, denial of the opportunity to 
vote or run for office, or fraud in counting ballots violates a political right. Likewise, as long as ballots are freely cast by eligible voters and counted equally, the voter (or candidate) may dislike the result but cannot dispute its validity.

\section{Concomitant Conditions}

The electoral components of democratic regimes are insufficient to ensure the proper functioning of democracy. For an electoral regime to enable institutionalized alternation, a set of concomitant conditions must be met that go beyond the institutions of an electoral regime, narrowly defined-that is, beyond voting. To return to table 1, these "concomitant conditions" or "surrounding rights and freedoms" (O'Donnell 2010, 20-24) include, at a minimum: freedom of expression, freedom of association and assembly, and access to alternative sources of information. Together the electoral components of the regime and their concomitant conditions constitute Dahl's "polyarchy" (1973, 2-3).

Surrounding rights and freedoms enable collective preference formation (Warren 2017, 44). Freedom of expression is necessary to ensure that the public can come to judgment on the choices they face. Likewise, freedom of association, which includes the right to form or join voluntary associations, including parties, and to assemble peacefully, is necessary for meaningful opposition. Voters cannot be expected to choose their representatives unless they have access to reliable information that reflects the full range of facts and opinions. However, the specific internal and external boundaries and content of these conditions cannot be stipulated a priori (O'Donnell 2010, 18-20). For example, the right to free speech or association must always be balanced against other rights and freedoms, and there are many ways of organizing media systems to ensure access to adequately diverse information. The external boundaries of these rights and freedoms (what specific rights and freedoms are necessary to ensure elections are free and fair in a particular context) and their internal content (what are acceptable restrictions, how vigorously they must be guaranteed) are "theoretically undecidable" (O’Donnell 2010, 22) and politically contested.

\section{Constitutionalism and the Rule of Law}

Concomitant rights and freedoms may become worthless parchment without enforcement by public authorities and compliance by citizens. To ensure that democratic alternation is fully institutionalized, it must be backed by a law-abiding and law-enforcing state (estado de derecho). The presence of such a state is not a definitional feature of democracy, but it provides democracy's organizational guarantee. A robust constitution - one supported by ingrained habits and dispositions, or what might be called a constitutional habitus — facilitates the practice of democracy; without it, democratic institutions may be impeccably formalized yet deficient in practice. This condition is essential to understanding the poor quality of democracy in many Latin American states (as well as its erosion in some exemplary democracies). ${ }^{10}$ 
In the Latin American context, the rule of law is often precarious and undemocratic, and this has led scholars in Latin America to refine democratic theory. For example, O'Donnell (1998) noted the weakness of "horizontal accountability" in Latin American democracies. Horizontal accountability means that within the state there are agencies "legally empowered — and factually willing and able_- to take actions ranging from routine oversight to criminal sanctions or impeachment in relation to possibly unlawful actions or omissions by other agents or agencies of the state" (O'Donnell 1998, 117). The absence of such mechanisms gives rise to delegative forms of rule. This diminished subtype of democracy does not generate the high levels of accountability that are generally considered desirable in fully democratic systems, even though vertical accountability, via alternation in power, is generally effective.

In delegative democracies, it is possible to periodically "throw the bums out," but much more difficult to influence how they govern while in office. This creates a temptation for leaders to abuse public office. The abuse of power motivates rulers to seek impunity, which violates the basic legal principle that nobody is above the law (de legibus solutis). Wherever impunity entrenches itself, the corruption of public offices tends to follow. A major source of impunity is the unregulated power of the armed forces. Civilian supremacy requires that the armed forces be nondeliberative and obedient. The long tradition of military interference in politics in Latin America, however, has created serious problems for democratic politics. Scholars have attended to this with a number of refinements that make the concept of democracy more precise without altering its essential meaning. ${ }^{11}$

\section{Refinements}

Three refinements are worth noting (see table 1). First, elected officials should not be subject to control by nonelected officials, whether by the presence of "authoritarian enclaves" in the state or overt military interference in civilian affairs (Garretón 1989, 51-62). In principle, this condition addresses the issue of civilian supremacy. However, it is possible to have an obedient and nondeliberative military that is under civilian control but that nonetheless insists on certain spheres of influence within which its power is unregulated. Second, nonelected officials should not arbitrarily terminate the mandate of elected officials (Valenzuela 2004). Third, the claim that there should be an even playing field for the opposition with respect to access to justice, the media, and state resources (Levitsky and Way 2002) is another welcome refinement, one that concerns both the electoral regime and surrounding rights and freedoms.

The first two refinements concern the problem of de facto powers. De facto powers are involved whenever there is obstruction of opposition or blockage in the alternation in power. The existence of de facto powers within a state-like civilian or military mafias that operate with impunity - is a definitional feature of authoritarianism (see Linz 2000, 159; O’Donnell 1999, 35-47). It is a feature that tends to accompany the absence of surrounding conditions, together with corruption of the electoral regime. By making the electoral regime a mere formality, a small group 
can exercise power without alternation in office. Such despotic power is precisely what the constitutional separation of powers and the rule of law are designed to discourage (Cameron 2013).

Electoral authoritarian regimes lie in the gray zone in which one or more of the electoral components of a political regime are compromised in a way that undermines the ability of elections to guarantee alternation in power and thus to check despotic power. These systems are typically characterized by violations or abuses of the rights and freedoms necessary for the normal functioning of the electoral regime, as well as constitutional irregularities, including excessive concentration of executive power. Such problems typically arise as an effect of the formation within the state of corrupt power elites who are unwilling to surrender office. The capacity of the regime's electoral components to generate alternation in power is diminished, typically as a result of mistreatment of the opposition. Furthermore, nondemocracies lacking meaningful electoral regimes occur when the erosion of the democratic features of a political regime reaches the point at which alternation in power and normal opposition activities are impossible. De facto powers within the regime refuse to surrender office and are prepared to use repression and violation of fundamental rights and freedoms to prevent the opposition from taking power.

\section{IMPLICATIONS FOR COMPETITIVE AUTHORITARIANISM: The “CAT-Dog” Problem}

The crucial difference between democratic and authoritarian regimes is whether citizens have the right and power to remove those in public office by means of contestation and participation through institutionalized elections, or whether de facto powers within the political system are able to perpetuate themselves in office through coercion. This is a clear distinction, and it merits intellectual allegiance. It is important to retain clear boundaries between the root concepts of democracy and authoritarianism, even as we generate hybrid regime concepts (Munck 2006, 28-33; Bogaard 2009; Morse 2012). Otherwise, combining concepts like democracy and authoritarianism risks generating concepts that are "radically confused" (Gallie 1955-56, 180). Giovanni Sartori warned that one of the dangers of misclassification is the creation of "catdogs" (Sartori 1991, 247-48). Cat-dogs do not exist; they are the result of mislabeling. To avoid the cat-dog problem, it is imperative that we distinguish poor-quality democracies from authoritarian regimes with democratic features. One advantage of disaggregating regimes is that it allows us to theorize the impact of the absence of one feature of a regime on the overall performance of that regime.

We may now revisit the challenges posed by competitive authoritarianism identified in the first section. First, making electoral competitiveness part of authoritarianism is potentially confusing. Competitiveness is a driver of alternation in power, which, as this article has stipulated, is a goal of any democratic system. Levitsky and Way quote with approval Andreas Schedler's claim that many hybrid regimes "violate 
minimal democratic norms so severely that it makes no sense to classify them as democracies, however qualified" (cited in Levistky and Way 2010a, 15). But the concept of competitive authoritarianism makes it hard to answer what counts as "so severely," because regimes cannot be considered minimally democratic unless elections are genuinely competitive. If we want to know whether a regime is democratic, we need to be able to assess whether competition is real and meaningful or just a façade.

Second, since rights and freedoms are part of the definition of democracy but the internal and external boundaries of the surrounding rights and freedoms are theoretically undecidable, analysts must make judgments concerning whether specific violations impair institutionalized alternation in power by means of participation and contestation within the regime. In this respect, it is crucial to recognize that liberal rights and freedoms may be precarious in countries with gross inequalities and historically entrenched patterns of exclusion and discrimination. Liberal rights and freedoms are universalistic. Rights are guaranteed to all, and enforced impartially. This demands a state capable of guaranteeing the rule of law and applying it impartially, including to those who occupy public office. Unevenness in the application of the law may indicate illiberalism, however, rather than a lack of democracy (Rhoden 2015).

Third, the presence of de facto powers deserves greater salience in the discussion of authoritarian regimes, including those that hold elections. This is an explicit concern of most of the refinements of the concept of democracy, and is implicit in the idea of an unlevel playing field. To be sufficient to classify a regime as authoritarian, however, de facto powers must have, and exercise, the capacity to disrupt the alternation in power.

In many cases it will be difficult to assess ex ante, or even ex post, whether observed behavior constitutes a violation of democratic standards sufficient to determine whether a regime is nondemocratic. ${ }^{12}$ Electoral authoritarianism tends to emerge endogenously by a process of muerte lenta - the slow-motion, gradual erosion of democracy—rather than by coups, military rebellions, insurgencies, or other violent events. ${ }^{13}$ Since we lack a clear understanding of how the gradual erosion of democracy culminates in authoritarian rule, we might want to think about how to use a disaggregated analysis of components of a political system to understand regime dynamics in the Andean subregion.

\section{REgIME DyNAMICS IN THE ANDES: AsSESSING THE RisK OF MUERTE LENTA}

At different times, Peru, Venezuela, Ecuador, and Bolivia, have met Levitsky and Way's (2010a) criteria for classification as competitive authoritarian regimes. ${ }^{14}$ Have all these cases eliminated institutionalized alternation in power by means of public participation and electoral contestation? The evidence is mixed. Two Andean regimes seem to fit the model reasonably well: Peru under Alberto Fujimori (19902000) and Venezuela under Hugo Chávez (1998-2013) and especially Nicolás Maduro (2013-present). The other cases are more ambiguous. 


\section{Peru}

The scholarly consensus supports the claim that Peru's regime was nondemocratic in the period 1992-2000 (see Carrión 2006; Cotler 1994; Levitsky and Loxton 2013, 121-22). President Fujimori enjoyed high popular approval during his tenure while his government committed gross abuses of human rights, largely because he was credited with success in the counterinsurgency struggle against Shining Path (Arce 2003). But even before he donned the presidential sash, Fujimori formed an alliance with a corrupt intelligence officer, Vladimiro Montesinos, who sought to exploit the emergency situation to control the armed forces, create a death squad linked to the intelligence services, and implement a plan to create a civil-military regime that would endure in power for decades. Montesinos implicated Fujimori in crimes against humanity, such as the 1991 Barrios Altos massacre, as a result of which the president could not leave office without facing trial or exile. ${ }^{15}$

On April 5, 1992, Fujimori closed Congress, suspended the constitution, and began to rule by degree. Facing domestic and international condemnation for this autogolpe (or presidential self-coup), he convened a Democratic Constituent Congress to rewrite the 1979 Constitution. The new 1993 Constitution, however, did not resolve the fundamental problem Fujimori faced, which was to assure impunity for himself and the armed forces. This was done by means of blackmail and bribery. The extensive abuses of power and corruption within the government meant that alternation in power became a threat to the interests of both civilian and military leaders. The regime collapsed when a video was leaked that made public the existence of a video archive documenting Vladimiro Montesinos's illegal activities. In November 2000, Fujimori fled into exile after tendering his resignation.

Although the 2000 election was not fraudulent in the conventional sensethere was no systematic vote stealing-it was unfair. Key media outlets were corrupted. The president's candidacy violated the 1993 Constitution and required dismantling the constitutional court and capturing electoral authorities. As a result, the integrity of the electoral regime was compromised. But the deeper problem was that the president was unwilling to accept that he had lost his majority in Congress. The leaked video showed Montesinos paying an opposition legislator to join the government caucus. The abuses of power and the unlevel playing field for the opposition were important, but they were also symptoms of something more sinister: a violent and corrupt civil-military shadow government that, once exposed, could not coexist with electoral democracy.

\section{Venezuela}

A consensus has emerged that Venezuela evolved into a hybrid regime over the course of Hugo Chávez's presidency (see Corrales 2015; Corrales and Penfold 2011; Mainwaring 2012; Levine 2017; Levitsky and Loxton 2013, 124-25), especially after 2006. Chávez came to power promising a "different model of democracy" (López Maya and Panzarelli 2013, 267)—different, that is, from the "partyarchy" of the Punto Fijo pact (McCoy 1999). The failure of the experiment in a 
more participatory or "radical democracy" (Ellner 2010, 79-84) meant that the basic goals democratic institutions are designed to achieve-agreement over election results, conflict resolution, and the gradual expansion of citizenship rightswere unattainable.

Chávez's first attempt to take power was through a coup in 1992. While in prison, he hatched a plan to use elections to create a constituent assembly that would wield unlimited sovereign power (Blanco Muñoz 1998). Chávez viewed his opposition as enemies to be crushed, not competitors with a right to share in power. Accordingly, the constituent assembly elections were designed to create an uneven playing field for the opposition parties, which were not even allowed to run under their own labels and which gained almost no representation. The opposition, for its part, having had little say in the making of the 1999 Constitution and finding itself displaced by the process of constitutional refounding, fought the government by extraconstitutional means-most dramatically in an unsuccessful coup attempt in April 2002.

Although Chávez won a string of elections between 1998 and 2012, they were marred by undemocratic practices: the government repeatedly prohibited candidates from running for office, without due process of law; opposition candidates and voters were intimidated and denied access to public resources; the names of voters who signed petitions for recall votes were made public; and when elected officials from the opposition won office, they had their functions restricted and budgets cut. Moreover, the militarization of the regime-reflected in the number of military officers occupying key ministries and governorships and the proliferation of armed militias - as well as the spread of corruption made it increasingly unlikely that the government would allow the opposition to take power.

The unraveling of the political system accelerated following Chávez's death in March 2013 (Mallen and García-Guadilla 2017, 144-50). The election of Maduro in April was closer than previous elections, and the opposition requested an annulment. In early 2014, massive protests erupted and claimed scores of lives. Legislative elections in 2015 produced a supermajority for the opposition (112 of 164 seats) in the National Assembly. The magistrates of the Supreme Judicial Tribunal challenged the outcome of four races in a transparent attempt to stymie the opposition. A supermajority would have allowed the opposition to appoint new magistrates and release political prisoners. When the National Assembly defied the Supreme Court, the court usurped the powers of the legislature, a move that was quickly challenged by the attorney general.

In another transparent effort to exclude the opposition, Maduro called for a new constituent assembly. Elections were held in July 2017. One of its first acts was to fire the attorney general and usurp the legislative powers of the National Assembly. The door to alternation in power by electoral means was thereby closed. In late 2017 a longtime observer of Venezuela wrote,

This regime wants above all to stay in power. Its principal leaders and enablers (army, national guard, police and political police, and paramilitaries) fear a loss of power which 
would limit their access to goods and funds, and make them vulnerable to legal and political processes, for example for violations of human rights, corruption, or drug trafficking. (Levine 2017)

It remains to be seen whether the authoritarian situation in Venezuela will lead to an authoritarian regime, a collapse of political order, or a restoration of electoral democracy. ${ }^{16}$

The political processes in Venezuela and Peru offer cautionary lessons for other countries in the region, but scholars should be equally cautious about lumping together diverse regimes. Should Bolivia under Evo Morales (2006-present) and Ecuador under Rafael Correa (2010-17) be placed under the same rubric as Fujimori's Peru and Chavista Venezuela? They certainly meet the conditions outlined by Levitsky and Way (2010a). However, the classification of these regimes has been the subject of considerable controversy (Mejía Acosta 2011; Wolff 2012; Anria 2013, 2016; De la Torre and Ortiz Lemos 2015; Conaghan 2011, 2016; Vera Rojas and Llanos-Escobar 2016; Tockman 2017).

Whereas Ecuador has been described as a defective democracy at risk of becoming authoritarian, Bolivia is undergoing an experiment in democratization that involves inclusionary practices like indigenous self-rule, as well as innovations in participation within the framework of representative institutions. In both cases, the failure to guarantee the integrity of the electoral components of the democratic regime or to fully respect surrounding rights and freedoms has diminished the capacity of these political systems to attain democratic goals. There is, however, less evidence of the rise of de facto powers within these regimes. Since little political violence has occurred in Ecuador and Bolivia, the armed forces have played a limited role: both regimes have remained unequivocally civilian (Blanco 2010, 335-38, 345-49). Indeed, Morales and Correa enjoyed broad support precisely because they helped restrain disorderly political processes. Morales's vice president, Álvaro García Linera, described Bolivia in the mid-2000s as a state of "catastrophic equilibrium" (2008). Five Ecuadorian presidents were defenestrated in the decade before Correa took office.

\section{Ecuador}

Under Correa, Ecuador, according to Carlos de la Torre and Andrés Ortiz Lemos, has undergone a "process of democratic erosion" that "might well result in the establishment of a competitive authoritarian regime" (2015, 223). Santiago Basabe-Serrano and Julián Martínez $(2014,146)$ are more unequivocal: Ecuador, they argue, "fully fits the concept of competitive authoritarianism," although they note that democracy would deteriorate further should Correa seek to perpetuate himself in power past 2017 (2014, 165-66). Sofía Vera Rojas and Santiago Llanos-Escobar (2016, 168-69) stress the deterioration of the quality of democracy without suggesting that Ecuador's political system has become nondemocratic. Basabe-Serrano and Martínez are on solid ground in arguing that Ecuador under Correa met Levitsky 
and Way's criteria for competitive authoritarianism, but the case has not yet been made that Ecuador's defective democracy cannot achieve the essential task of alternating of power by means of electoral contestation.

From the outset, it was obvious that Correa would weaken the constitutional order. When he ran for president in 2006 as a political outsider, he did not even present a congressional slate. Once elected, and following a controversial referendum, he convened a constituent assembly that assumed full legislative powers, thereby weakening the legislature and enabling the president to restructure and stack the Supreme Court. The new constitution was approved in 2008, and Correa was re-elected the following year. Levitsky and Loxton $(2013,121)$ refer to this as a coup, and they suggest that it "ushered in a competitive authoritarian regime."

There is no question that Correa used government resources, media intimidation, and political control over the courts and electoral institutions to harass and bully the opposition. This has led to valid complaints about the unfairness of electoral processes. At the same time, Correa earned a job approval rating consistently above 60 percent throughout his decade in power, and satisfaction with the functioning of democracy increased under his tenure (Montalvo and Zechmeister 2017). Correa's popularity provided cover for the spread of authoritarian practices and institutions in the state.

Significantly, however, in 2017 Correa stepped down to let his vice president, Lenín Moreno, run as the candidate of the ruling party, Movimiento Alianza País. Moreno won by a narrow margin (51 percent), which the opposition Movimiento Creo, led by Guillermo Lasso, denounced as fraudulent. The election result was consistent with public opinion polls (Montalvo and Zechmeister 2017), and no firm evidence of systematic fraud was presented, but the contention confirmed a lack of confidence in elections among the opposition. To the surprise of many, however, Moreno acted quickly to distance himself from Correa, pursuing corruption investigations against his own vice president, thawing relations with the press, and rebuilding connections with indigenous organizations, all of which provoked harsh criticism from Correa. Although it is possible that Ecuador will continue to experience an erosion of democracy under Moreno, particularly if he insists on retaining the authoritarian powers Correa accumulated, it is premature to conclude that Ecuador has become an electoral authoritarian regime.

\section{Bolivia}

Some scholars suggest that Bolivia has a strong claim to classification as a democracy (Anria 2016; Tockman 2017), while others place it in the category of competitive authoritarianism, or at least moving in that direction (Levitsky and Loxton 2013, 117-18; Lehoucq 2008; Weyland 2013). Since the election of Evo Morales and the Movimiento al Socialismo (MAS) in 2005, the content and boundaries of rights and freedoms have shifted in Bolivia. Some aspects of the constitutional order have been weakened, while power has been concentrated in the executive-especially since the MAS took control of the legislature in 2009. 
On the other hand, in response to the longstanding demands of the social movements that propelled the MAS into power, Morales convened a constituent assembly without shuttering or usurping the powers of the sitting congress. Indeed, when the MAS-dominated constituent assembly's draft failed to win the approval of the legally required supermajority, the text was sent to the congress for revision and amendments, one of which was the two-term limit. The revised text was then submitted to a referendum, and it won by a solid 61 percent. The new constitution, adopted in 2009, appears to have institutionalized agreement on a conception of democracy that contains direct, representative, and communitarian features (Exeni Rodríguez 2012).

During Morales's presidency, elections have been conducted under the auspices of international observers and have generated decisive outcomes. Morales faced major opposition from traditional political elites, particularly at the subnational level, and, like Chávez, he has shown considerable impatience with opposition. Opponents have been persecuted by judicial means (Levitsky and Loxton 2013, 117-18). Tensions reached a critical level around 2008-9, but they were resolved peacefully, through elections, rather than by force. Morales's dependence on social movement support, both inside and outside the MAS, made it highly unlikely that he could successfully hold on to power in the face of an electoral defeat or a collapse of popular support (see, e.g., Mejía Acosta 2011; Anria 2016).

Bolivia has not been immune to problems typical of defective democracies. In February 2016, Morales attempted, by means of a referendum, to change the new constitution to allow him to run for a third term in 2019. The public narrowly (51 percent) rejected the initiative, and Morales appeared to accept the result. Rather than cultivate a successor, however, he began to seek re-election by other means. The MAS requested that the Plurinational Constitutional Tribunal remove constitutional term limits on the grounds that they violated Morales's human right to run for office. The tribunal accepted the argument, clearing the way for Morales to run again. The decision illustrates the precarious institutionality of Bolivian judicial institutions and the MAS's dependence on Morales. Morales may fear that if he should lose power he would be treated as he has treated his opponents. His bid for re-election is an ill omen, but reports of the death of Bolivian democracy have been, so far, greatly exaggerated.

\section{POLICY IMPLICATIONS of Disaggregating Democracy}

Assessments of political regimes are highly consequential. Countries in good standing in the club of democracies enjoy extensive diplomatic and material advantages, and loss of standing can result in penalties. The claim, for example, that any state in the Americas does not meet minimal standards of democracy carries with it the implication that the state should be excluded from the region's primary multilateral institution, the Organization of American States (OAS). The Inter-American Democratic Charter, signed by OAS member states in 2001, makes respect for democ- 
racy a condition of OAS membership. However, the charter does not specify what counts as an interruption or alteration of a constitutional democratic order.

Scholarship should enable judgments about such matters, but if scholarly work is to be useful to policymakers, it is imperative that researchers stipulate the criteria by which the international community may judge a country to be in good standing as a democracy. If policymakers were to use the theory of competitive authoritarianism as their guide, a large number of countries would have to be expelled from the OAS. This complicates dialogue between scholars and policymakers.

Moreover, since the repertoire of actions available to domestic opponents and the international community hinges on the characterization of political systems, risks are entailed when the term authoritarian is used to describe regimes that still enjoy electoral legitimacy. The strategies and tactics that are appropriate in seeking to topple an authoritarian regime-including the use of violence and the demand for the termination of mandates before the end of term and outside the constitutional calendar - are quite unlike those appropriate in a functioning, albeit defective, democracy. The accurate characterization of regimes is especially sensitive in an era when coups still occur, sometimes at the instigation of groups in civil society.

Policymakers need tools for preventive diplomacy, including graduated responses to incremental erosions of democracy. An effective system of democracy protection in the Americas requires that policymakers have the discernment to know the difference between a minor crisis—such as might be handled through the InterAmerican Commission on Human Rights—and a situation that "seriously impairs the democratic order in a member state" and thus might trigger Article 19 of the Democratic Charter. A major advantage of disaggregating democracy is that it enables the judicious assessments necessary for graduated responses. ${ }^{17}$ Policymakers need to grasp both the dynamics of gradual regime change and the crucial threshold at which a system can no longer ensure the alternation of power. To do this effectively demands an understanding of how violations of the rule of law open the door to systematic abuses of power, how systematic abuses of power lead to impunity and enable actions that cause de facto powers within the regime to fear opposition and alternation in power, how this can lead to violations of the integrity of the electoral components of the regime, and why all these developments happen. ${ }^{18}$

\section{CONCLUSIONS}

Democratization research could profit from a deeper dialogue between scholars working on hybrid regimes and those in the tradition of democratic theory pioneered by Guillermo O’Donnell $(2010,1999)$. As scholarship shifts from a focus on diminished subtypes of democracy to hybrid regimes, it is important to build cumulatively on earlier debates. This article began by acknowledging that research on hybrid regimes captures an important insight: not only are elections insufficient to establish the democratic bona fides of a political system, but they also play an important role in certain nondemocratic regimes. It is also possible for authoritarian practices and institutions to be introduced into democratic regimes. 
For some scholars, this realization has led to a strong urge to use the label authoritarianism. Writing about regimes that "violate minimal democratic norms so severely that it makes no sense to classify them as democracies, however qualified," Andreas Schedler argues that the "time has come to abandon misleading labels and to take their nondemocratic nature seriously" (quoted in Levitsky and Way 2010a, 15). This point is well taken, but the nondemocratic features of hybrid regimes can be recognized without sacrificing a clear distinction between democracy and authoritarianism.

Upholding this distinction is not the same as insisting on a minimalist concept of democracy. As O'Donnell demonstrated, minimalist conceptions of democracy tend to assume the presence of conditions that are rarely explicitly stated by democratic theorists-and that are often absent in the Latin American context (O'Donnell 2010, 13-17). These include many of the conditions emphasized by Levitsky and Way: respect for civil and political freedoms, a free press, and a functioning bureaucracy. O'Donnell's solution, however, was not to include all these components in his definition of democracy, but instead to theorize the conditions enabling institutionalized, inclusive, fair, and competitive elections (O'Donnell 2010; McGuire 2014; Vargas Cullell 2014).

In a similar spirit, theories of hybrid regimes may begin with the conditions that enable regimes to perform the goals intrinsic to their design. Using this as a baseline, we may then examine the effects of the partial absence of these conditions. If regimes have genuinely authoritarian features, some democratic goals will be unattainable. It is precisely for this reason that many hybrid regimes are unstable. There is a tension between popular leaders' need to continuously demonstrate electoral success and their persistent efforts to corrupt political institutions, which, as a result, may fail to generate agreement on whether incumbents possess the authority to rule. This tension is exacerbated when rulers rely on de facto powers and commit abuses that make it harder for them to contemplate surrendering power, due to the fear of reprisals, prosecution, or exile. Yet instead of consolidating authoritarian rule, such abuses often provoke political crises and civil society uprisings.

Consequently, the breakdown of democracy does not necessarily lead to the consolidation of authoritarian alternatives. In no Andean country has an authoritarian regime yet been consolidated. Fujimori failed to construct a durable civil-military regime, and Venezuela's political future remains uncertain. In fact, it is unclear that authoritarianism of any sort constitutes a viable alternative to democracy in this subregion. Autocratic rulers may push regimes to the limit of their capacity to function democratically, and beyond, but the construction of a system of government based on anything other than electoral legitimacy is extremely difficult, precisely because such regimes fail to solve the fundamental problems that democracies, with all their flaws, are equipped to address. The most nondemocratic regimes we observe in the region have tended to become Mafia-riven, corrupt, and violent political systems that fall apart under the weight of internal tensions and civil society resistance. Such democratic resilience should serve as a corrective to excessive pessimism. 


\section{NOTES}

The author is grateful for the advice and guidance of the editors and anonymous reviewers of this journal, as well as conversations or correspondence with Gerry Munck, Agustín Goenaga, Wolfgang Merkel, Eric Hershberg, Michael McCarthy, Adrian Gurza Lavalle, Sinesio López, Dominique Rumeau, Jason Tockman, Zaraí Toledo, Magdalena Ugarte, Netina Tan, Pablo Policzer, Franz Barrios, Julio Ugarte, David Collier, Steve Levitsky, and Santiago Anria. Participants in a conference at the Kellogg Institute at the University of Notre Dame, a CLACSO working group held in Lima, a seminar at the Fundación Friedrich Ebert in La Paz, and a talk at the Centro de Estudios Superiores Universitarios, Universidad Mayor San Simón, in Cochabamba also helped the development of the argument. Funding was provided by the Social Sciences and Humanities Research Council of Canada. The author alone is responsible for the content of this article.

1. See the thematic issue of the Journal of Democracy under the rubric Delegative Democracy Revisited (2016) on the relevance of O'Donnell's concept of delegative democracy, especially Luna and Vergara 2016.

2. Andreas Schedler (2006) uses the less ambiguous term electoral authoritarianism.

3. Levitsky and Loxton $(2013,113-14)$ identify five cases of competitive authoritarianism in the Andes between 1990 and 2010. They label Venezuela under Hugo Chávez (and presumably this would hold for Nicolás Maduro after 2013); Ecuador, first under Lucio Gutiérrez and then under Rafael Correa; and, with qualifications, Bolivia under Evo Morales_-but not Colombia under Álvaro Uribe (see note 14) —as competitive authoritarian regimes. See also Mainwaring 2012, 963; Weyland 2013, 19-20, 32. In a subsequent article, however, Levitsky and Way $(2015,47)$ suggest that Bolivia and Ecuador "remained borderline democracies," and only Venezuela was an "unambiguously democratic regime that collapsed and remained authoritarian in 2014."

4. For an excellent discussion of O'Donnell's work, see Vargas Cullell 2014.

5. For reasons that will become obvious, the term competitive is eschewed in favor of electoral authoritarianism.

6. Access to private resources and media by nonincumbents does not appear to concern Levitsky and Way, despite the heavy concentration of media assets in many Latin American countries, the media's often manipulative and undemocratic role in politics, and unequal access to the private financing of election campaigns. Even if we accept the focus on the needs of opposition groups for public resources, it is unclear what we would have to see in terms of unequal distribution of access before we knew we were observing a competitive authoritarian regime.

7. Munck (2006, 28) claims that "a central issue raised by the recent literature on hybrid regimes concerns the identification of thresholds that establish boundaries between categories and between cases."

8. Elsewhere they write, "opposition groups compete in a meaningful way for executive power" (Levitsky and Way 2010a, 7).

9. O’Donnell (2010) uses the term institutionalized wager.

10. The term habitus is a Latin translation of the Greek hexis, used by Aristotle to refer to the habits and dispositions of citizens and rulers, which he believed could sustain or corrupt regimes. Interest in the concept has been renewed by the insightful work of Pierre Bourdieu $(1990,52-65)$.

11. On "precising," see Collier and Levitsky 1997.

12. I am grateful to an anonymous reviewer for this point. 
13. I am grateful to Fernando Mayorga for this point. The phrase muerte lenta is from O’Donnell 2011, 30.

14. Levitsky and Loxton $(2013,113)$ argue that Colombia under President Álvaro Uribe (2002-10) did not fall into the category of electoral authoritarianism, despite serious human rights abuses, because the government did not skew the playing field against political opposition. Given its illegal wiretapping of the opposition and media, however, this raises the question, how skewed must the playing field be? More significantly, Colombia's democracy was corrupted by the political influence of drug traffickers in Congress, without whom Uribe did not have a majority, as the parapolitica scandal revealed (see Bejarano et al. 2010, 127 28). I agree that Colombia remained a democracy in this period, albeit a defective one. A major source of the regime's resilience was the horizontal accountability created by the 1991 Constitution. When Uribe attempted to remain in office beyond the constitutional two-term limit, he was blocked by the courts (Boesten 2014).

15. Fujimori received lengthy sentences for his crimes.

16. I use the term situation rather than regime in the spirit of Juan Linz's diagnosis of military rule in Brazil (1973).

17. See the thematic issue of Latin American Policy, especially Legler et al. (2012), and the 2003 issue of Canadian Foreign Policy, 10, 3: 1-116.

18. In the Peruvian election of 2016, poor-quality electoral institutions affected the outcome of a presidential election, and yet Peru remains a democracy, albeit a defective one, since the principle of alternation in power was not violated. The weakness of political parties is one of Peru's perennial problems (Cameron and Levitsky 2003).

\section{REFERENCES}

Anria, Santiago. 2013. Social Movements, Party Organization, and Populism: Insights from the Bolivian MAS. Latin American Politics and Society 55, 3: 19-46.

. 2016. Delegative Democracy Revisited: More Inclusion, Less Liberalism in Bolivia. Journal of Democracy 27, 3: 99-108.

Arce, Moisés. 2003. Political Violence and Presidential Approval in Peru. Journal of Politics 65, 2: 572-83.

Basabe-Serrano, Santiago, and Julián Martínez. 2014. Ecuador: cada vez menos democracia, cada vez más autoritarismo...con elecciones. Revista de Ciencia Política 34, 1: 145-70.

Bejarano, Ana María, Helena Alviar, Felipe Botero, Gary Hoskin, and Mónica Pachón. 2010. Colombia: "Democracia amenazada." In Cameron and Luna 2010. 101-64.

Blanco, Carlos. 2010. Relaciones cívico-militares y el papel de las fuerzas armadas en los países andinos y en Chile. In Cameron and Luna 2010. 315-69.

Blanco Muñoz, Agustín. 1998. Habla el comandante. Caracas: Catedra Pio Tamayo/CEHA/ IIES/ FACES/UCV.

Boesten, Jan. 2014. Between Democratic Security and Democratic Legality: Constitutional Politics and Presidential Re-election in Colombia. Precedente: Revista Jurídica 5: 9-40.

Bogaards, Matthijs. 2009. How to Classify Hybrid Regimes? Defective Democracy and Electoral Authoritarianism. Democratization 16, 2: 399-423.

Bourdieu, Pierre. 1990. The Logic of Practice. Trans. Richard Nice. Stanford: Stanford University Press.

Cameron, Maxwell A. 2013. Strong Constitutions: Socio-Cognitive Origins of the Separation of Powers. New York: Oxford University Press. 
Cameron, Maxwell A., and Juan Pablo Luna, eds. 2010. Democracia en la región andina: diversidad y desafios. Lima: Instituto de Estudios Peruanos.

Cameron, Maxwell A., and Steven Levitsky. 2003. Democracy Without Parties? Political Parties and Regime Change in Fujimori's Peru. Latin American Politics and Society 45, 3: 1-33.

Carothers, Thomas. 2002. The End of the Transition Paradigm. Journal of Democracy 13, 1 : $5-21$.

Carrión, Julio, ed. 2006. The Fujimori Legacy: The Rise of Electoral Authoritarianism. University Park: Pennsylvania State University Press.

Collier, David, and Steven Levitsky. 1997. Democracy with Adjectives: Conceptual Innovation in Comparative Research. World Politics 49, 3: 430-51.

- 2009. Democracy: Conceptual Hierarchies in Comparative Research. In Concepts and Methods in the Social Sciences: The Tradition of Giovanni Sartori, ed. David Collier and John Gerring. London: Routledge. 269-88.

Conaghan, Catherine. 2011. Ecuador: Rafael Correa and the Citizens' Revolution. In The Resurgence of the Latin American Left, ed. Steven Levitsky and Kenneth M. Roberts. Baltimore: Johns Hopkins University Press. 260-82.

- 2016. Ecuador Under Correa. Journal of Democracy 27, 3: 109-18.

Corrales, Javier. 2015. Autocratic Legalism in Venezuela. Journal of Democracy 26, 2: 37-51.

Corrales, Javier, and Michael Penfold. 2011. Dragon in the Tropics: Hugo Chavez and the Political Economy of Revolution in Venezuela. Washington, DC: Brookings Institution Press.

Cotler, Julio. 1994. Politica y sociedad en el Perú: cambios y continuidades. Lima: Instituto de Estudios Peruanos.

Dahl, Robert A. 1973. Polyarchy: Participation and Opposition. New Haven: Yale University Press.

- 1989. Democracy and Its Critics. New Haven: Yale University Press.

De la Torre, Carlos, and Andrés Ortiz Lemos. 2015. Populist Polarization and the Slow Death of Democracy in Ecuador. Democratization 23, 2: 1-21.

Diamond, Larry. 2015. Facing Up to the Democratic Recession. Journal of Democracy 26, 1 : $141-55$.

Ellner, Steve. 2010. Hugo Chávez's First Decade in Office: Breakthroughs and Shortcomings. Latin American Perspectives 170, 37: 77-96.

Exeni Rodríguez, José Luis. 2012. Elusive Demodiversity in Bolivia: Between Representation, Participation, and Self-Government. In New Institutions for Participatory Democracy in Latin America: Voice and Consequence, ed. Maxwell A. Cameron, Eric Hershberg, and Kenneth E. Sharpe. New York: Palgrave Macmillan. 207-29.

Gallie, W. B. 1955-56. Essentially Contested Concepts. Proceedings of the Aristotelian Society 56: $167-98$.

García Linera, Álvaro. 2008. Álvaro García Linera: Catastrophic Equilibrium and Point of Bifurcation. Translation, notes, and introduction by Richard Fidler. Bolivia Rising, June 27. http://boliviarising.blogspot.ca/2008/06/alvaro-García-linera-catastrophic.html. Accessed October 27, 2017.

Garretón, Manuel Antonio. 1989. La posibilidad democrática en Chile. Cuadernos de Difusión. Santiago, Chile: FLACSO.

Goertz, Gary. 2006. Social Science Concepts: A User's Guide. Princeton: Princeton University Press.

Journal of Democracy. 2016. Delegative Democracy Revisited. Theme issue. 27, 3 (July).

Legler, Thomas, Riyad Insanally, Santiago Mariani, and Timothy M. Shaw. 2012. The Democratic Charter: The State of the Debate. Latin American Policy 3, 1: 3-12. 
Lehoucq, Fabrice. 2008. Bolivia's Constitutional Breakdown. Journal of Democracy 19, 4: $110-24$.

Levine, Daniel H. 2017. The Authoritarian Gambit. LASA Forum 48, 4: 1-3.

Levitsky, Steven, and James Loxton. 2013. Populism and Competitive Authoritarianism in the Andes. Democratization 20, 1: 107-36.

Levitsky, Steven, and Lucan A. Way. 2002. The Rise of Competitive Authoritarianism. Journal of Democracy 13, 2: 51-65.

- 2010a. Competitive Authoritarianism: Hybrid Regimes After the Cold War. Cambridge: Cambridge University Press.

- 2010b. Why Democracy Needs a Level Playing Field. Journal of Democracy 21, 1: $57-68$.

- 2015. The Myth of Democratic Recession. Journal of Democracy 26, 1: 45-58.

Linz, Juan J. 1973. The Future of an Authoritarian Situation or the Institutionalization of an Authoritarian Regime: The Case of Brazil. In Authoritarian Brazil, ed. Alfred Stepan. New Haven: Yale University Press. 233-54.

- 2000. Totalitarian and Authoritarian Regimes. Boulder: Lynne Rienner.

López Maya, Margarita, and Alexandra Panzarelli. 2013. Populism, Rentierism, and Socialism in the Twenty-First Century: The Case of Venezuela. In Latin American Populism in the Twenty-First Century, ed. Carlos de la Torre and Cynthia J. Arnson. Washington, DC/Baltimore: Woodrow Wilson Center Press/Johns Hopkins University Press. 239-68.

Luna, Juan Pablo, and Alberto Vergara. 2016. Latin America's Problems of Success. Journal of Democracy 27, 3: 158-65.

Mainwaring, Scott. 2012. From Representative Democracy to Participatory Competitive Authoritarianism: Hugo Chávez and Venezuelan Politics. Perspectives on Politics 10, 4: 955-67.

Mainwaring, Scott, Ana María Bejarano, and Eduardo Pizarro Leongómez, eds. 2006. The Crisis of Democratic Representation in the Andes. Stanford: Stanford University Press.

Mallén, Ana L., and María Pilar García-Guadilla. 2017. Venezuela's Polarized Politics: The Paradox of Direct Democracy Under Chávez. Boulder: Lynne Rienner.

McCoy, Jennifer L. 1999. Chávez and the End of "Partyarchy" in Venezuela. Journal of Democracy 10, 3: 64-76.

McGuire, James W. 2014. Democracy, Agency, and the Classification of Political Regimes. In Reflections on Uneven Democracies: The Legacy of Guillermo O'Donnell, ed. Daniel Brinks, Marcelo Leiras, and Scott Mainwaring. Baltimore: Johns Hopkins University Press. 287-310.

Mejía Acosta, Andrés. 2011. ¿Revolución o delegación ciudadana? Democracia, gobierno y rendición de cuentas en Ecuador. In Democracia delegativa, ed. Guillermo O’Donnell, Osvaldo Iazzetta, and Hugo Quiroga. Buenos Aires: Prometeo. 139-59.

Merkel, Wolfgang. 2004. Embedded and Defective Democracies. Democratization 11, 5: 33-58.

Montalvo, Daniel J., and Elizabeth J. Zechmeister. 2017. AmericasBarometer Brief: Ecuador 2016/17. Nashville: Vanderbilt University. https://www.vanderbilt.edu/lapop/ecuador/ AB2016_Ecuador_RRR_Presentation_W_082417.pdf. Accessed October 27, 2017.

Morse, Yonatan L. 2012. The Era of Electoral Authoritarianism. World Politics 64, 1: 16198.

Munck, Gerardo L. 2006. Drawing Boundaries: How to Craft Intermediate Regime Categories. In Electoral Authoritarianism: The Dynamics of Unfree Competition, ed. Andreas Schedler. Boulder: Lynne Rienner. 27-40.

O’Donnell, Guillermo. 1994. Delegative Democracy. Journal of Democracy 5, 1: 55-69. 
1996. Illusions About Consolidation. Journal of Democracy 7, 2: 34-51.

1998. Horizontal Accountability in New Democracies. Journal of Democracy 9, 3: $112-26$.

-1999. Counterpoints: Selected Essays on Authoritarianism and Democratization. Notre Dame: University of Notre Dame Press.

— 2001. Democracy, Law, and Comparative Politics. Studies in Comparative International Development 36, 1: 7-36.

- 2010. Democracy, Agency, and the State: Theory with Comparative Intent. New York: Oxford University Press.

. 2011. Nuevas reflexiones acerca de la democracia delegativa (DD). In Democracia delegativa, ed. O’Donnell, Osvaldo Iazzetta, and Hugo Quiroga. Buenos Aires: Prometeo. 19-32.

O'Donnell, Guillermo, and Philippe C. Schmitter. 1986. Transitions from Authoritarian Rule: Tentative Conclusions About Uncertain Democracies. Baltimore: Johns Hopkins University Press.

Pérez-Liñán, Aníbal. 2007. Presidential Impeachment and the New Political Instability in Latin America. Cambridge: Cambridge University Press.

Plattner, Marc F. 2014. The End of the Transitions Era? Journal of Democracy 25, 3: 5-16.

Przeworski, Adam. 1991. Democracy and the Market. New York: Cambridge University Press.

Ragin, Charles C. 1997. Turning the Tables: How Case-Oriented Research Challenges Variable-Oriented Research. Comparative Social Research 16: 27-42.

Rhoden, T. F. 2015. The Liberal in Liberal Democracy. Democratization 22, 3: 560-78.

Roberts, Kenneth M. 2007. Latin America's Populist Revival. SAIS Review 27, 1: 3-15.

Sartori, Giovanni. 1962. Democratic Theory. Detroit: Wayne State University Press.

- 1970. Concept Misformation in Comparative Politics. American Political Science Review 64, 4: 1033-53.

- 1991. Comparing and Miscomparing. Journal of Theoretical Politics 3, 3: 243-57.

Schedler, Andreas. 2006. The Logic of Electoral Authoritarianism. In Electoral Authoritarianism: The Dynamics of Unfree Competition, ed. Schedler. Boulder: Lynne Rienner. 1-23.

Slater, Dan. 2013. Democratic Careening. World Politics 65, 4: 729-63.

Tockman, Jason. 2017. Hegemony of Representation: Democracy and Indigenous Self-government in Bolivia. Journal of Politics in Latin America 9, 2: 121-38.

Valenzuela, Arturo. 2004. Latin American Presidencies Interrupted. Journal of Democracy 15, 4: 5-19.

Vargas Cullell, Jorge. 2014. Democracy and Democratization: Guillermo O’Donnell's Late Attempt to Rework Democratic Theory. In Reflections on Uneven Democracies: The Legacy of Guillermo O'Donnell, ed. Daniel Brinks, Marcelo Leiras, and Scott Mainwaring. Baltimore: Johns Hopkins University Press. 311-30.

Vera Rojas, Sofía, and Santiago Llanos-Escobar. 2016. Ecuador: la democracia después de nueve años de la "Revolución Ciudadana" de Rafael Correa. Revista de Ciencia Política 36, 1: 145-75.

Warren, Mark. 2017. A Problem-Based Approach to Democratic Theory. American Political Science Review 111, 1: 39-53.

Weyland, Kurt. 2013. The Threat from the Populist Left. Journal of Democracy 24, 3: 18-32. Wolff, Jonas. 2012. New Constitutions and the Transformation of Democracy in Ecuador and Bolivia. In New Constitutionalism in Latin America: Promises and Practices, ed. Detlef Nolte and Almut Schilling-Vacaflor. Farnham: Ashgate. 183-202.

Zakaria, Fareed. 1997. The Rise of Illiberal Democracy. Foreign Affairs 76, 6: 22-43. 